\title{
Remarkable Antimicrobial Resistance in Nosocomial Spontaneous Bacterial Peritonitis
}

\author{
Nozokomiyal Spontan Bakteriyel Peritonitte Dikkat Çekici Antibiyotik Direnci
}

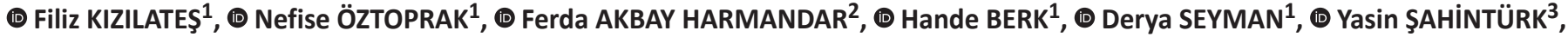 \\ (1) Ayhan Hilmi ÇEKiN ${ }^{2}$, (1) Yeşim ÇEKiN ${ }^{4}$ \\ 1 University of Health Sciences, Antalya Training and Research Hospital, Clinic of Infectious Diseases and Clinical Microbiology, Antalya, Turkey \\ 2 University of Health Sciences, Antalya Training and Research Hospital, Clinic of Gastroenterology, Antalya, Turkey \\ 3 University of Health Sciences, Antalya Training and Research Hospital, Clinic of Internal Medicine, Antalya, Turkey \\ 4University of Health Sciences, Antalya Training and Research Hospital, Clinic of Medical Microbiology, Antalya, Turkey
}

\section{Abstract}

Introduction: The aim of this prospective observational study was to investigate the causative agents and their susceptibility to antimicrobial drugs in patients with nosocomial spontaneous bacterial peritonitis (SBP) in order to clarify empirical antimicrobial treatment.

Materials and Methods: Patients who were admitted to the Gastroenterology Department of Antalya Training and Research Hospital with prediagnosis of SBP during the period of January 2011 to December 2014 were enrolled in the study. Spontaneous bacterial peritonitis was defined as ascitic fluid with polymorphonuclear leukocyte count $\geq 250$ cells $/ \mathrm{mm}^{3}$. Spontaneous bacterial peritonitis was considered to be nosocomial if diagnosed after $>48$ hours of hospitalization. During the study period, cefotaxime was the preferred empirical antimicrobial therapy in our center. If there was no clinical recovery after 48 hours or cefotaxime-resistant bacteria was identified in culture, antimicrobial therapy was switched.

Results: The proportion of culture-positive SBP was 13\% (57/439). In total, 46\% (202/439) of the cases were neutrocytic ascites and 52.6\% (30/57) were evaluated as nosocomial SBP. Candida spp. was the causative agent in one case, which was not included in the calculation. The overall natural/ acquired cefotaxime resistance was 51.8\% (29/56). The rate of cefotaxime resistance was 66.7\% (20/30) in nosocomial SBP, significantly higher than in non-nosocomial infections $(34.6 \% ; 9 / 26, p=0.04)$. Resistance to gentamicin, trimethoprim-sulfamethoxazole, and carbapenems were also significantly higher in nosocomial infections $(p=0.04, p=0.04, p=0.02)$.

Conclusion: Cefotaxime resistance was found to be higher in nosocomial SBP than non-nosocomial cases. Therefore, determining whether an infection is nosocomial is beneficial when selecting empirical antibiotic therapy.

Keywords: Extended-spectrum beta-lactamases, antimicrobial resistance, surveillance, community-acquired infections, culture-negative neutrocytic ascites

\section{$\ddot{0} z$}

Giriş: Bu prospektif gözlemsel çalışmanın amacı; nozokomiyal spontan bakteriyel peritonit (SBP) olgularında, ampirik antibiyotik tedavisini planlamak için, etken mikroorganizmaları ve antimikrobiyal ilaçlara duyarlılıklarını ortaya koymaktır.

Gereç ve Yöntem: Çalışmaya Ocak 2011 ile Aralık 2014 arasında SBP ön tanısı ile Antalya Eğitim ve Araştırma Hastanesi Gastroenteroloji Kliniği'ne başvuran hastalar dahil edildi. Assit sıvısında polimorfonüklear hücre sayısı $\geq 250$ hücre/mm³ olan olgular SBP olarak tanımlandı. Hastaneye yatıştan 48 saat veya daha sonra tanı konulan olgular nozokomiyal olarak kabul edildi. Çalışmanın yapıldığı dönemde hastanemizde ampirik tedavide sefotaksim tercih edilmekte idi. Eğer 48 saatte klinik yanıt alınmadıysa veya kültürde sefotaksim dirençli bakteri ürediyse tedavi değişikliği yapılmakta idi. Bulgular: Kültür-pozitif SBP oranı \%13 (57/439) idi. Olguların \%46'sı (202/439) nötrositik asitti. Olguların \%52,6'sı (30/57) nozokomiyal SBP olarak değerlendirildi. Bir olguda etken Candida spp. idi, bu nedenle hesaplamaya dahil edilmedi. Tüm olgularda doğal/kazanılmış sefotaksim direnci \%51,8 (29/56) idi. Nozokomiyal SBP olgularında sefotaksim direnci \%66,7 (20/30) idi ve non-nozokomiyal olgulardan anlamlı ölçüde yüksekti (\%34,6;

Cite this article as: Kızılateş F, Öztoprak N, Akbay Harmandar F, Berk H, Seyman D, Şahintürk Y, Çekin AH, Çekin Y. Remarkable Antimicrobial Resistance in Nosocomial Spontaneous Bacterial Peritonitis. Mediterr J Infect Microb Antimicrob. 2019;8:11. 
$9 / 26, p=0,04)$. Nozokomiyal enfeksiyonlarda gentamisin, trimetoprim-sulfametoksazol ve karbapenem direnci de anlamlı derecedeyüksekti $(p=0,04$, $p=0,04, p=0,02$ ).

Sonuç: Nozokomiyal SBP olgularında sefotaksim direnci yüksek olarak saptandı. Bu nedenle ampirik antibiyoterapiyi planlarken, enfeksiyonun nozokomiyal olup olmamasına göre belirlemek faydalı olacaktır.

Anahtar Kelimeler: Genişlemiş spektrumlu beta-laktamazlar, antimikrobiyal direnç, sürveyans, toplum kaynaklı enfeksiyonlar, kültür negatif nötrositik assit

\section{Introduction}

Spontaneous bacterial peritonitis (SBP) is a common and lifethreatening complication that occurs in cirrhotic patients with ascites and is associated with an increased risk of mortality. Spontaneous bacterial peritonitis is defined as a bacterial infection of ascitic fluid in patients with no intra-abdominal, surgically-treatable source of infection and is diagnosed in the presence of polymorphonuclear leukocyte (PMN) count over $250 / \mathrm{mm}^{3}$ in the ascitic fluid ${ }^{[1]}$. There is an increased risk of mortality, hepatic encephalopathy, and hepatorenal syndrome in SBP patients. Therefore, early diagnosis and rapid management are important in the management. Empirical antimicrobial therapy is the best strategy against cirrhosis decompensation and complications due to low possibility of ascitic fluid culture positivity and delay in culture results. Hence, "Which antibiotic is the best choice for empirical treatment?" is a frequently asked question.

The most common microorganisms isolated from ascitic fluid of patients with SBP are Escherichia coli, Klebsiella pneumoniae, and Gram-positive cocci such as Streptococcus and Enterococcus spp. ${ }^{[2-4]}$. E. coli and K. pneumoniae are the causative agents in nearly $50 \%$ of cases $^{[2,5-7]}$. The fact that enteric Gram-negative bacteria are the causative agents in more than half of cases implicates the intestinal flora as the source of the infection ${ }^{[4-7]}$. Gram-positive bacteria [Staphylococcus aureus (2-4\%), Enterococcus spp. (6-10\%)] are responsible for approximately $25 \%$ of cases ${ }^{[8,9]}$. Anaerobic bacteria are detected at a rate of $1 \% 0^{[9]}$. However, recent studies point to an increase in the proportion of SBP cases caused by Gram-positive bacteria ${ }^{[3]}$.

According to guidelines from the American Association for the Study of Liver Diseases and European Association for the Study of the Liver, a third-generation cephalosporin such as cefotaxime should be initiated immediately after the diagnosis of neutrocytic ascites without waiting for culture results ${ }^{[3,8,10-12]}$. Cefotaxime appears to cover 95\% of the intestinal facultative anaerobic flora, which includes the most common isolates, $E$. coli and K. pneumoniae, and it reaches high concentrations in ascitic fluid. The reduction in clinical and microbiological response to third-generation cephalosporins over the last decade necessitates the classification of infections into community-acquired and nosocomial infections. Recent studies indicate that up to $33-75 \%$ of patients with nosocomial infection fail to respond to third-generation cephalosporins due to multidrug-resistant bacteria ${ }^{[13-17]}$. The rate of complications and mortality may increase among these patients due to high resistance rates, prompting some experts to suggest the use of broad-spectrum antibiotics such as carbapenem plus daptomycin or linezolid in the empirical treatment of nosocomial $\mathrm{SBP}^{[18]}$. However, this approach may further increase resistance to these antimicrobial agents and reduce the treatment success of complicated infections in the future. Therefore, it seems useful to know the potential regional causative agents and their antimicrobial resistance patterns in order to recommend empirical antimicrobial treatment.

The aim of this study was to investigate the causative bacteria and their susceptibility patterns to antimicrobial agents in patients with nosocomial SBP in order to clarify the empirical antimicrobial treatment.

\section{Materials and Methods}

This prospective observational study was conducted on cirrhotic patients with ascites and were hospitalized in the Gastroenterology Department of the Antalya Training and Research Hospital between January 01, 2011 and December 31, 2014. Ascitic fluid samples of cirrhotic patients were obtained at the time of admission with prediagnosis of peritonitis. Only one sample per patient per hospital stay was included in the study. If a patient was admitted more than two times during a 10day period, only the first hospital stay was included. Malignant ascites (proved by pathological examination) and bacterascites (evaluated as skin contamination, no clinical symptoms and isolation of skin bacterial flora members) were also excluded. Multiple isolates of the same strain from one patient were counted only once. Spontaneous bacterial peritonitis was defined as ascitic fluid with PMN count $\geq 250$ cells $/ \mathrm{mm}^{3}$. Ascitic fluid with PMN count $\geq 250$ cells $/ \mathrm{mm}^{3}$ and no growth in the culture was defined as culture-negative neutrocytic ascites (CNNA $)^{[1]}$. Spontaneous bacterial peritonitis was considered to 
be nosocomial if developed and diagnosed after more than 48 hours of hospitalization ${ }^{[13]}$.

Demographic characteristics of the patients were determined by interview; clinical characteristics and laboratory findings were obtained from medical charts. Ascitic fluid samples were collected by paracentesis when infection was suspected. Leukocyte count was performed with full automated blood count system (Beckman Coulter Diagnostics, USA) and PMN were counted with a Thoma cell counting chamber under direct microscopy. Ascitic fluid cultures were performed by conventional methods and automated blood culture system. Ascitic fluid samples less than $5 \mathrm{ml}$ were subcultured onto sheep blood agar and MacConkey agar and incubated at 37 ${ }^{\circ} \mathrm{C}$ for 48 hours. The other samples were subcultured to blood culture bottles and incubated in an automated BACTEC 9120 system (Becton Dickenson Diagnostic Instrument System, Sparks, USA) for up to seven days. Bacterial identification was performed by conventional methods using a BD Phoenix automated identification and antimicrobial sensitivity system (Becton Dickenson Diagnostic Instrument System, Sparks, USA). Antimicrobial susceptibility test was performed by disk diffusion method according to the 2013 version of the Clinical and Laboratory Standards Institute criteria and by BD Phoenix system. Leukocyte count, culture results, C-reactive protein (CRP), and erythrocyte sedimentation rate were recorded. Repeated paracentesis was performed after 48 hours.

During the study period, cefotaxime was administered as the first line therapy in our hospital. If there was no clinical recovery after 48 hours or cefotaxime-resistant bacteria was identified in bacterial culture, antimicrobial therapy was switched to piperacillin-tazobactam or carbapenems.

This study was approved by Antalya Training and Research Hospital Ethics Committee (Protocol number: 37/10) on March 20, 2014.

\section{Statistical Analysis}

Data were analysed via SPSS version 20.0 (Statistical Package for the Social Sciences, Chicago, Illinois, USA) software. Variables were expressed as mean \pm standard deviation and percentage $(\%)$. Categorical variables were compared using the chi-square test, Fisher's exact test, or Student's t-test. P values less than 0.05 were accepted as statistically significant.

\section{Results}

A total of 439 ascitic fluid samples from 172 cirrhotic patients were included in the study. The mean age of patients was $61.71 \pm 14.18$ years and $62(36 \%)$ of them were female. Of the 172 patients, etiology of hepatic insufficiency was alcoholic liver disease in 33 (19.2\%), hepatitis B virus-related cirrhosis in $37(21.5 \%)$, hepatitis C virus-related cirrhosis in 29 (16.8\%), primary biliary cirrhosis in $12(7.0 \%)$, and cryptogenic cirrhosis in $61(35.5 \%)$ patients. Of the 439 ascitic fluid samples, 46\% (202/439) were neutrocytic ascites. The proportion of culturepositive SBP was 13\% (57/439). There was no growth in the other 145 of the 202 neutrocytic ascites samples and they were considered to be CNNA (33\%; 145/439).

The rate of positive microbiological culture among ascitic fluid samples with $P M N \geq 250$ cells $/ \mathrm{mm}^{3}$ was $28.2 \%$ (57/202). Of the 202 neutrocytic ascites samples, 74.3\% (150/202) had been cultured onto automated blood culture system and 25.7\% (52/202) had been cultured onto blood agar and MacConkey agar by conventional methods. The positivity rates in automated blood culture system and conventional method were 28.6\% (43/150) and 26.9\% (14/52), respectively, with no significant difference in positivity rates according to culture method ( $p>0.05)$.

Mean PMN counts in ascitic fluid and CRP values were significantly higher in patients with SBP compared to CNNA $(3075.43 \pm 3485.75$ vs. $1423.44 \pm 1969.10$ and $63.80 \pm 51.45$ vs. $45.66 \pm 38.15$, respectively) $(p<0.05)$ (Table 1$)$.

Gram-negative bacteria accounted for 57.9\% (33/57) of the isolated microorganisms and the most frequently isolated agents were E. coli (52.6\%), coagulase-negative Staphylococci (CNS) (19.2\%), and Enterococcus spp. (14\%). The prevalence of extended-spectrum beta-lactamase (ESBL) production was $17.5 \%(10 / 57)$.

Nosocomial SBP accounted for 52.6\% of SBP cases (30/57). There was no significant difference between the causative agents in nosocomial versus non-nosocomial cases (Table 2).

The overall natural/acquired cefotaxime resistance was 51.8\% (29/56) among causative agents of SBP. The identification of cefotaxime-resistant agents was summarized in Table 3. Candida spp. was the causative agent in one case, which

Table 1. Comparison of laboratory findings

\begin{tabular}{l|l|l|l}
\hline & Spontaneous bacterial peritonitis & Culture-negative neutrocytic ascites & $\mathbf{p}$ \\
\hline Ascites PMN* count $\left(\right.$ mean $\left._{ \pm} \mathrm{SD}\right)$ & $3075.43 \pm 3485.75$ & $1423.44 \pm 1969.10$ & 0.01 \\
\hline $\mathrm{CRP}(\mathrm{mg} / \mathrm{l})($ mean $\pm \mathrm{SD})$ & $63.80 \pm 51.45$ & $45.66 \pm 38.15$ & 0.01 \\
\hline Sedimentation rate $(\mathrm{mm} /$ hour) $($ mean $\pm \mathrm{SD})$ & $32.00 \pm 17.09$ & $32.05 \pm 17.80$ & $>0.05$ \\
\hline
\end{tabular}

*PMN: Polymorphonuclear leukocytes, CRP: C-reactive protein, SD: Standard deviation 
was not included in the calculation. Resistance rates to ciprofloxacin, gentamicin, ampicillin-sulbactam, trimethoprimsulfamethoxazole, piperacillin-tazobactam, and carbapenems were 28.6\% (16/56), 23.2\% (13/56), 46.4\% (26/56), 39.3\% (22/56), 28.6\% (16/56), and 12.5\% (7/56), respectively (Table 4).

Resistance to cefotaxime was observed in 66.7\% (20/30) of nosocomial SBP cases and was significantly more frequent than in non-nosocomial infections [34.6\% (9/26)] ( $p=0.004)$. In addition, nosocomial infections had significantly higher rates of resistance to gentamicin ( $33.3 \%$ vs. $11.5 \%, p=0.04$ ), trimethoprimsulfamethoxazole ( $53.3 \%$ vs. $23.1 \%, p=0.04$ ), and carbapenems
(20.0\% vs. $3.8 \%, p=0.02)$ (Table 4). Rates of resistance to piperacillin-tazobactam were $33.3 \%(10 / 30)$ in nosocomial and $11.5 \%(6 / 26)$ in non-nosocomial infections. The proportion of ESBL-producing isolates was similar between the two groups (nosocomial, 16.6\%; non-nosocomial, 19.2\%, p>0.05).

\section{Discussion}

Spontaneous bacterial peritonitis is the most common infectious complication of cirrhosis, affecting 8-27\% of cirrhotic patients with ascites who are admitted to hospital and causing 20-40\% mortality ${ }^{[4,10,11,19]}$. Spontaneous bacterial peritonitis is reported

Table 2. Distribution of causative agents in nosocomial/non-nosocomial spontaneous bacterial peritonitis

\begin{tabular}{|c|c|c|c|}
\hline Bacteria n (\%) & $\begin{array}{l}\text { Nosocomial spontaneous bacterial } \\
\text { peritonitis }(n=30)\end{array}$ & $\begin{array}{l}\text { Non-nosocomial spontaneous bacterial } \\
\text { peritonitis }(n=26)\end{array}$ & $p$ value \\
\hline Acinetobacter spp. & $1(3.3)$ & - & - \\
\hline Escherichia coli & $14(46.7)$ & $16(61.6)$ & $>0.05$ \\
\hline Enterobacter spp. & - & $1(3.9)$ & - \\
\hline Enterococcus spp. & $4(13.4)$ & $4(15.3)$ & - \\
\hline $\begin{array}{l}\text { Coagulase-negative } \\
\text { Staphylococci }\end{array}$ & $7(23.4)$ & 4 (15.3) & $>0.05$ \\
\hline Klebsiella spp. & - & $1(3.9)$ & - \\
\hline Staphylococcus aureus & $1(3.3)$ & - & \\
\hline Listeria monocytogenes & $2(6.6)$ & - & - \\
\hline Streptococcus spp. & $1(3.3)$ & - & - \\
\hline Total & $30(100)$ & $26(100)$ & \\
\hline
\end{tabular}

Table 3. Identification of cefotaxime-resistant Isolates in nosocomial/non-nosocomial spontaneous bacterial peritonitis

\begin{tabular}{l|l|l|l|l}
\hline & \multicolumn{2}{|c|}{ Nosocomial (n=20) } & \multicolumn{2}{c}{ Non-nosocomial (n=9) } \\
\hline Bacteria & $\begin{array}{l}\text { Number of } \\
\text { isolates }\end{array}$ & $\begin{array}{l}\text { Mechanism of } \\
\text { resistance }\end{array}$ & $\begin{array}{l}\text { Number of } \\
\text { isolates }\end{array}$ & Mechanism of resistance \\
\hline Acinetobacter baumannii & 1 & Natural & - & \\
\hline Enterococcus spp. & 4 & Natural & 4 & Natural \\
\hline Listeria monocytogenes & 2 & Natural & - & \\
\hline Coagulase-negative Staphylococci & 5 & Acquired & - & Acquired \\
\hline Enterobacter spp. & - & & 1 & Acquired \\
\hline Escherichia coli & 7 & Acquired & 4 & - \\
\hline Streptococcus spp. & 1 & Acquired & - & \\
\hline
\end{tabular}

Table 4. Antimicrobial resistance in nosocomial versus non-nosocomial spontaneous bacterial peritonitis

\begin{tabular}{|c|c|c|c|}
\hline Antibiotic & $\begin{array}{l}\text { Nosocomial spontaneous bacterial } \\
\text { peritonitis }(n=30) \\
\text { Resistance } n(\%)\end{array}$ & $\begin{array}{l}\text { Non-nosocomial spontaneous bacterial } \\
\text { peritonitis }(n=26) \\
\text { Resistance } n(\%)\end{array}$ & $\mathbf{p}$ \\
\hline Ampicillin sulbactam & $16(53.3)$ & $10(38.5)$ & $>0.05$ \\
\hline Ciprofloxacin & $11(36.7)$ & 5 (19.2) & $>0.05$ \\
\hline Cefotaxime & $20(66.7)$ & $9(34.6)$ & $<0.05$ \\
\hline Gentamicin & $10(33.3)$ & $3(11.5)$ & $<0.05$ \\
\hline Trimethoprim-sulfamethoxazole & $16(53.3)$ & $6(23.1)$ & $<0.05$ \\
\hline Piperacillin-tazobactam & $10(33.3)$ & $6(11.5)$ & $>0.05$ \\
\hline Carbapenems & $6(20.0)$ & $1(3.8)$ & $<0.05$ \\
\hline
\end{tabular}


at a rate of 3.5-33.3\% in cirrhotic patients ${ }^{[20-23]}$. The prevalence of culture-positive SBP in our study was 13\%, consistent with the literature.

Causative agents were identified in $28.2 \%$ of neutrocytic ascites samples. The bacterial concentration in ascitic fluid is usually very low in SBP, approximately 2 bacteria/ $/ \mathrm{mm}^{3[24]}$. Therefore, it is recommended to culture at least $10 \mathrm{ml}$ of ascitic fluid into a blood culture bottle at bedside in order to identify bacterial growth in culture ${ }^{[7,9,24]}$. Culturing into blood culture bottles has been reported to increase bacterial growth by $40 \%\left[0^{[7,25]}\right.$. Nevertheless, there was no significant difference between conventional culture and blood culture methods in our study $(p>0.05)$. The detection of causative agents in the culture ranges from $12.6 \%$ to $68.4 \%$ in neutrocytic ascite ${ }^{[26,27]}$. Low positivity rates may be related to persistence of the inflammatory process despite bacterial eradication. Immune activation due to binding of bacterial DNA in ascitic fluid to toll-like receptor-9 has been demonstrated previously; therefore, it should be kept in mind that bacterial DNA, not the bacterium itself, may trigger the inflammatory process, which may be related to the lack of culture growth in the CNNA group ${ }^{[28]}$.

In our study the most frequent causative agents were $E$. coli (53.6\%), CNS (19.6\%), and Enterococcus spp. (14\%). E. coli is the most frequently isolated causative agent in SBP, with rates ranging between $30-60 \% \%^{[4,19,26,28]}$. Some recent reports have pointed out the change in SBP microbiological profile as increased isolation of Gram-positive microorganisms, especially in patients receiving norfloxacin prophylaxis ${ }^{[3,5,10,14]}$. In this study, enterococci were isolated in 14\% of patients. Three years ago, the proportion of enterococci in SBP was $11.1 \%$ in our center ${ }^{[23]}$. According to our findings, cases of SBP associated with enterococci increased by $3.2 \%$ in a 2-year period. According to Reuken et al. ${ }^{[29]}$, SBP cases associated with enterococci increased from $11 \%$ to $35 \%$ over a period of 12 years ${ }^{[6,14]}$. Enterococci are known to be intrinsically resistant to third-generation cephalosporins, the first choice of empirical antimicrobial therapy ${ }^{[10,11,30]}$. For this reason, empirical therapy should be expanded to be effective against enterococci in centers with high enterococcal SBP rates.

It is a fact that resistance to third-generation cephalosporins has increased among the causative agents of SBP in recent years. Studies from European countries especially have reported resistance and a relationship between inappropriate antibiotic use versus mortality ${ }^{[1,14,31]}$. In the present study, the overall cefotaxime resistance rate was $51.8 \%$ but increased to $66.7 \%$ in the nosocomial SBP group. Due to the significantly higher rate of cefotaxime in the nosocomial isolates, cefotaxime as a first-line therapy failed to eradicate the infection in these cases. There are few studies comparing the microbiological and clinical characteristics of nosocomial and non-nosocomial
SBP and different results have been reported in terms of antimicrobial resistance. Kim et al. ${ }^{[32]}$ reported similar clinical and microbiological characteristics among nosocomial and community-acquired SBP, whereas Bert et al. ${ }^{[33]}$ indicated increased resistance to cefotaxime and amoxicillin-clavulanic acid among nosocomial isolates. Fernandez et al. ${ }^{[13]}$ reported clinical efficacy in only $26 \%$ of patients with nosocomial SBP treated with third-generation cephalosporins. Thus, it is important for centers to determine the regional causative agents and their antibiotic resistance. In our center, the higher rate of cefotaxime resistance among nosocomial SBP is due to higher proportion of CNS and enterococci rather than to a higher proportion of cefotaxime-resistant Gram-negative bacteria. The high prevalence of enterococci in some centers highlights the combined empirical antimicrobial treatment of nosocomial SBP and confirms the need to cover the spectrum of Gram-positive bacteria. A new study is planned in our center to describe the risk factors of SBP caused by staphylococci and enterococci in order to define a combined empirical antimicrobial treatment.

In our study, we could only discriminate SBP as nosocomial or non-nosocomial. It would be more useful to distinguish the infections as nosocomial (diagnosis made after more than 48 hours of hospitalization), community-acquired (diagnosis made within 48 hours of hospitalization in patients with no contact with the healthcare system, defined as hemodialysis or chemotherapy in the 30 days previous to the episode or more than two days at the day hospital, visits to the emergency department and/or previous admission to the hospital in the three months previous to the episode), and healthcareassociated (diagnosis made within 48 hours of hospitalization in patients with prior contact with the healthcare system ${ }^{[1]}$. Friedman et al. ${ }^{[34]}$ determined a similar microbiological profile among patients with nosocomial bacteremia and patients who had close contact with healthcare systems.

In this study we could not identify the risk factors of cefotaximeresistance and enterococcal infections. In addition, we could not evaluate clinical response to first-line therapy in patients with CNNA. A prospective study has been planned to address these limitations.

\section{Conclusion}

Recently, researchers have reported declines in clinical and microbiological response to third-generation cephalosporins, a commonly used first-line therapy in the empirical antimicrobial treatment of SBP. Especially in nosocomial cases, they recommend the use of piperacillin-tazobactam or carbapenems with daptomycin ${ }^{[12,35]}$. Therefore, it is beneficial to determine whether an infection is nosocomial or not when deciding empirical antimicrobial therapy for patients with neutrocytic 
ascites. In light of our findings, piperacillin-tazobactam or carbapenem should be preferred as first-line therapy in our center if SBP is evaluated as nosocomial.

\section{Ethics}

Ethics Committee Approval: This study was approved by Antalya Training and Research Hospital Ethics Committee (Protocol number: 37/10) on March 20, 2014.

Informed Consent: Consent form was filled out by all participants.

Peer-review: Externally and internally peer-reviewed.

\section{Authorship Contributions}

Surgical and Medical Practices: F.A.H., Y.Ş., A.H.Ç., Concept: F.K. A.H.Ç., Design: N.Ö., H.B., Data Collection or Processing: D.S., H.B., Analysis or Interpretation: F.K., A.H.Ç., Literature Search: D.S., F.A.H., Writing: F.K.

Conflict of Interest: No conflict of interest was declared by the authors.

Financial Disclosure: The authors declared that this study received no financial support.

\section{References}

1. Rimola A, Garcia-Tsao G, Navasa M, Piddock $\amalg$, Planas R, Bernard B, Inadomi JM. Diagnosis, treatment and prophylaxis of spontaneous bacterial peritonitis: a consensus document. International Ascites Club. J Hepatol. 2000;32:142-53.

2. Koulaouzidis A, Bhat S, Saeed AA. Spontaneous bacterial peritonitis. World J Gastroenterol. 2009;19:1042-9.

3. Piroth L, Pechinot A, Di Martino V, Hansmann Y, Putot A, Patry I, Hadou T, Jaulhac B, Chirouze C, Rabaud C, Lozniewski A, Neuwirth C, Chavanet $\mathrm{P}$, Minello A. Evolving epidemiology and antimicrobial resistance in spontaneous bacterial peritonitis: a two year observational study. BMC Infect Dis. 2014;14:287.

4. Guarner C, Soriano G. Spontaneous bacterial peritonitis. Semin Liver Dis. 1997:17:203-17.

5. Park MK, Lee JH, Byun YH, Lee H, Gwak GY, Choi MS, Koh KC, Paik SW, Yoo BC, Rhee JC. Changes in the profiles of causative agents and antibiotic resistance rate for spontaneous bacterial peritonitis: an analysis of cultured microorganism in recent 12 years. Korean J Hepatol. 2007;13:370-7.

6. Frances R, Gonzalez-Navajas JM, Zapater P, Munoz C, Cano R, Pascual S, Santana F, Marquez D, Perez-Mateo M, Such J. Translocation of bacterial DNA from Gram-positive microorganisms is associated with a speciesspecific inflammatory response in serum and ascitic fluid of patients with cirrhosis. Clin Exp Immunol. 2007;150:230-7.

7. Runyon BA, Canawati HN, Akriviadis EA. Optimization of ascitic fluid culture technique. Gastroenterology. 1988;95:1351-5.

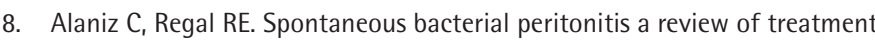
options. P T. 2009;34:205-10.

9. Riggio 0, Angeloni S. Ascitic fluid analysis for diagnosis and monitoring of spontaneous bacterial peritonitis. World J Gastroenterol. 2009;15:3845-50

10. Sheer TA, Runyon BA. Spontaneous Bacterial Peritonitis. Dig Dis. 2005;23:3946.
11. Wiest R, Krag A, Gerbes A. Spontaneous bacterial peritonitis: recent guidelines and beyond. Gut. 2012;61:297-310.

12. Piano $S$, Fasolato $S$, Salinas $F$, Romano $A$, Tonon $M$, Morando $F$, Cavallin M, Gola E, Sticca A, Loregian A, Palu G, Zanus G, Senzolo M, Burra P, Cillo $U$, Angeli P. The empirical antibiotic treatment of nosocomial spontaneous bacterial peritonitis: Results of a randomized, controlled clinical trial. Hepatology. 2016;63:1299-309.

13. Fernandez J, Acevedo J, Castro M, Garcia O, de Lope CR, Roca D, Pavesi M, Sola E, Moreira L, Silva A, Seva-Pereira T, Corradi F, Mensa J, Gines P, Arroyo $\mathrm{V}$. Prevalence and risk factors of infections by multiresistant bacteria in cirrhosis: a prospective study. Hepatology. 2012;55:1551-61.

14. Ariza X, Castellote J, Lora-Tamayo J, Girbau A, Salord S, Rota R, Ariza J, Xiol $X$. Risk factors for resistance to ceftriaxone and its impact on mortality in community, healthcare and nosocomial spontaneous bacterial peritonitis. J Hepatol. 2012;56:825-32.

15. Fernandez J, Navasa M, Gomez J, Colmenero J, Vila J, Arroyo V, Rodes J. Bacterial infections in cirrhosis: epidemiological changes with invasive procedures and norfloxacin prophylaxis. Hepatology. 2002;35:140-8.

16. Tandon P, Delisle A, Topal JE, Garcia-Tsao G. high prevalence of antibioticresistant bacterial infections among patients with cirrhosis at a US liver center. Clin Gastroenterol Hepatol. 2012;10:1291-8.

17. Merli M, Lucidi C, Giannelli V, Giusto M, Riggio O, Falcone M, Ridola L, Attili AF, Venditti M. Cirrhotic patients are at risk for healthcare-associated bacterial infections. Clin Gastroenterol Hepatol. 2010;8:979-85.

18. Zhang YM, Yu W, Zhou N, Li JZ, Xu LC, Xie ZY, Lu YF, Li U. High frequency of thrombocytopenia in patients with acute-on-chronic liver failure treated with linezolid. Hepatobilliary Pancreat Dis Int. 2015;14:287-92.

19. Kamani L, Mumtaz K, Ahmed U, Ali AW, Jafri W. Outcomes in culture positive and culture negative ascitic fluid infection in patients with viral cirrhosis: cohort study. BMC Gastroenterol. 2008;8:59-60.

20. Guarner C, Sola R, Soriano G, Andreu M, Navella MT, Vila MC, Sabat M, Coll S, Ortiz J, Gomez C, Balanzo J. Risk of a first community-acquired spontaneous bacterial peritonitis in cirrhotics with low ascitic fluid protein levels. Gastroenterology. 1999;117:414-9.

21. Evans LT, Kim WR, Poterucha JJ, Kamath PS. Spontaneous bacterial peritonitis in asymptomatic outpatients with cirrhotic ascites. Hepatology. 2003;37:897-901.

22. Syed VA, Ansari JA, Karki P, Regmi M, Khanal B. Spontaneous bacteria peritonitis (SBP) in cirrhotic ascites: a prospective study in a tertiary care hospital, Nepal. Kathmandu Univ Med J. 2007:5:48-59.

23. Cekin Y, Cekin AH, Duman A, Yilmaz U, Yesil B, Yolcular BO. The role of serum procalcitonin levels in predicting ascitic fluid infection in hospitalized cirrhotic and non-cirrhotic patients. Int J Med Sci. 2013;10:1367-74.

24. Runyon BA. Spontaneous bacterial peritonitis: An explosion of information Hepatology. 1988;8:171-5.

25. Wong CL, Holroyd-Leduc J, Thorpe KE, Straus SE. Does this patient have bacterial peritonitis or portal hypertension? How do I perform a paracentesis and analyze the results? JAMA. 2008;299:1166-78.

26. Reginato TJ, Oliveira MJ, Moreira LC, Lamanna A, Acencio MM, Antonangelo L. Characteristics of ascitic fluid from patients with suspected spontaneous bacterial peritonitis in emergency units at a tertiary hospital. San Paulo Med j. 2011;12:315-9.

27. Figueiredo FA, Coelho HS, Soares JA. Spontaneous bacterial peritonitis in hepatic cirrhosis: prevalence, predictive factors and prognosis. Rev Assoc Med Bras 1999:45:128-36.

28. Runyon BA, Hoefs JC, Morgan TR. Ascitic fluid analysis in malignancyrelated ascites. Hepatology. 1988;8:1104-9.

29. Reuken PA, Pletz MW, Baier M, Pfister W, Stallmach A, Bruns T. Emergence of spontaneous bacterial peritonitis due to Enterococci-risk factors 
and outcome in 12-year retrospective study. Aliment Pharmacol Ther. 2012;35:1199-208.

30. Yakar T, Güçlü M, Serin E, Alişkan H, Husamettin E. A recent evaluation of empirical cephalosporin treatment and antibiotic resistance of changing bacterial profiles in spontaneous bacterial peritonitis. Dig Dis Sci. 2010;55:1149-54.

31. Novovic S, Semb S, Olsen H, Moser C, Knudsen JD, Homann C. First-line treatment with cephalosporins in spontaneous bacterial peritonitis provides poor antibiotic coverage. Scand J Gastroenterol. 2012;47:212-6.

32. Kim SU, Chon YE, Lee CK, Park JY, Kim DY, Han KH, Chan CY, Kim S, Jung KS, Ahn SH. Spontaneous bacterial peritonitis in patients with Hepatitis B virus-related cirrhosis: Community-acquired versus nosocomial. Yonsei Med J 2012;53:328-36.
33. Bert F, Andreu M, Durand F, Degos F, Galdbard JO, Moreau R, Branger C, Lambert-Zechovsky N, Valla D. Nosocomial and community-acquired spontaneous bacterial peritonitis: comparative microbiology and therapeutic implications. Eur J Clin Microbiol Infect Dis. 2003;22:10-5.

34. Friedman ND, Kaye KS, Stout JE, McGarry SA, Trivette SL, Briggs JP, Lamm W, Clarck C, MacFarquhar J, Walton AL, Reller LB, Sexton DJ. Healthcareassociated bloodstream infections in adults: a reason to change the accepted definition of community-acquired infections. Ann Intern Med. 2002;137:791-7.

35. Shi L, Wu D, Liu S, Zhao P, Tu B, Xie Y, Liu Y, Wang X, Liu L, Zhang X, $X u Z$, Wang $F$, Qin E. Nosocomial and community-acquired spontaneous bacterial peritonitis in patients with liver cirrhosis in China: Comparative microbiology and therapeutic implications. Sci Rep. 2016;7:46025. 